\title{
Effect of Foliar Nutrients on Wheat Seed (Triticum aestivum 1.) Productivity Under Lower Gangetic Alluvial Soil of West Bengal
}

\author{
Saptarshi Bagchi1 \\ 1Depatment of Seed Science and Technology, \\ Institute of Agriculture, \\ University of Calcutta, \\ Ballygunge, West Bengal, India.
}

\begin{abstract}
In present day quality crop cultivation is the prime objective for achieving the desire seed yield. The current problem of wheat cultivation is contributing in low yield due to use of old technology like unawareness about the efficient method and time of application of fertilizer etc. The present price hike of fertilizers is one of the main constraints to increase the economic yield of crops. Thus efforts are needed to minimize its losses and to enhance its economic use. Foliar nutrients play a vital role in cultivation of cereal crops for increasing seed yield \& productivity in a sustainable manner. The present experiment has been designed to critically observe into matter by scanning out the combination of foliar nutrients in grain filling and seed yield of wheat. There were altogether nine treatments of supplementary foliar nutrients along with water spray at $50 \%$ flowering and grain filling stages. The investigation clearly shows that significantly highest seed yield $\left(2840 \mathrm{~kg} \mathrm{ha}^{-1}\right)$ with foliar application of $\mathrm{NaCl}$ @ $0.5 \%$. Lowest seed yield $\left(2220 \mathrm{~kg} \mathrm{ha}^{-1}\right)$ was observed in water sprayed control treatment. The seed yield was increased up to $27.92 \%$ with the application of $\mathrm{NaCl} @$ $0.5 \%$ over control.
\end{abstract}

Keywords:- Foliar Nutrients; Seed Yield; Test Weight.

\section{INTRODUCTION}

To meet the high demand of food grains of burgeoning population, agricultural production must be increased. Therefore we must develop genotypes and devise production technologies to enhance productivity and quality under Global Climate Change scenario.

Wheat, a fine cereal, has played a stellar role in India's transformation from its ship-to-mouth existence of the 1960s to exporting grains as at present. With an output of 103.59 million tonnes harvested from 29.32 million hectares in 2018-1 [1], the country has emerged as the world's second largest producer of wheat (next only to China) [2]. Rising demand and trailing production are posing challenges. The productivity of wheat which was $2602 \mathrm{~kg} \mathrm{ha}^{-1}$ in 2004-05 has increased to $3533 \mathrm{~kg} \mathrm{ha}^{-1}$ in 2018-19 [1].

\author{
Ria Biswas2* \\ 2Depatment of Agricultural Statistics, \\ Bidhan Chandra Krishi Viswavidyalaya, \\ Mohanpur, Nadia, West Bengal, India.
}

\begin{abstract}
The current problem of wheat cultivation contributing in low yield is the use of old technology like unawareness about the efficient method and time of application of fertilizer etc. Foliar applications of micro and macronutrients are more effective in term of getting maximum yield and reduce losses. Moreover, fertilizers are energy intensive to produce and are very expensive. The present price hike of fertilizers is one of the main constraints to increase the economic yield of crops. Thus efforts are needed to minimize its losses and to enhance its economic use. Foliar fertilization, that is nutrient supplementation through leaves, is an efficient technique of fertilization which enhances the availability of nutrients. It has been observed that utilization of fertilizers especially urea applied through soil is not as effective as when it is supplied to the plant through foliage along with soil application [3]. It also ensures the ample availability of nutrients to crops for obtaining higher yield [4]. Several researchers justified the idea that nutrients (like $\mathrm{N}$ ) may be taken up through roots and leaves and may spread within the plant [5] [6]. The efficiency of $\mathrm{N}$ assimilation through foliage, however, depends upon several factors including varieties or genotypes. Foliar spray of potassium in combination with nitrogen and some micro-nutrients like zinc had significant effect on grain yield of wheat [7].
\end{abstract}

To provide plant nutrients in critical period, foliar application is a bare necessity. Many investigators concluded that foliar application of nutrients sources during growth stage increased grain and straw yields, grain weight, biological yield, grain nutrients concentration and grain protein content [8][9] [10][11][12][13] [14] and [15]. Foliar feeding has proved to be the fastest way of curing nutrient deficiencies and boosting plant performances at specific physiological stages.

There is a direct link between foliar feeding and the activities of the enzymatic systems of the plant. Foliar fertilization is an effective way of quickly supplying plant nutrients during critical periods of flowering and grain fill at which time soil or root conditions are often unfavourable for optimum root uptake and there is insufficient uptake to supply demand. 
Sodium (Na) is not an essential element for plants but can be used in small quantities as micro-nutrients, to aid in metabolism and synthesis of chlorophyll (Chl.). Chloride is needed in small quantities and plays an important role in plant metabolism, photosynthesis, osmosis (movement of water in and out of plant cells) and ionic balance within the cell. Sodium $(\mathrm{Na})$ and Potassium $(\mathrm{K})$ are chemically and structurally similar monovalent cations. The hydrated Sodium $\left(\mathrm{Na}^{+}\right)$ion has a radius of $0.358 \mathrm{~nm}$, while Potassium $\left(\mathrm{K}^{+}\right)$ion has a radius of $0.331 \mathrm{~nm}$; thus, it does not appear that size would be the basis for any major discrimination in uptake between $\mathrm{Na}$ and $\mathrm{K}$ through ion channels [16]. The application of $\mathrm{Na}$ to the growth medium has been shown to stimulate the growth of many species, including asparagus, barley, broccoli, Brussels sprout, caraway, carrot, chicory, cotton, flax, millet, oat, pea, rutabaga, tomato, vetch, wheat, cabbage, celeriac, horseradish, kale, kohlrabi, mustard, radish, rape, celery, mangel, sugar beet, red beet, Swiss chard, and turnip [17][18].

However, Das and Sarkar [19] showed it beyond doubt that, with introduction of physiological drought at late grain filling stage i.e. 21 days after $50 \%$ flowering (60 to 63 days after sowing in late sown wheat crop) the mobilization of stored photosynthates from plant body giving higher grain yield. Grain yield is also influenced by temperature extremities of high temperatures. In persuasion of the results that spraying of $0.5 \% \mathrm{NaCl}$ solution at $50 \%$ flowers and 10 days after $50 \%$ flowering resulting in higher grain yield of wheat.

Chlorine $(\mathrm{Cl})$ has a number of benefits to plant growth. Chloride, a micro-nutrient takes partin different plant functions. Combination with Potassium (K), Chlorine (Cl) gets involve in plants stomatal openings. Through the utilization of these two elements, the plant is able to control its internal water balance. Many diseases in different crops were reported to be suppressed by Chlorine at the levels of macro-nutrients [20]. But, the question arises now, what is the optimum concentration of foliar solution that is to be applied 21 days after peak flowering (which is 7 days after $50 \%$ flowering) to get the best effect simultaneously taking economic condition of the farmer into account. With this idea in view an experiment was planned to study the effect of foliar nutrients on seed yield of wheat.

\section{MATERIALS AND METHODS}

The present experiment designed to study the performance of wheat (Triticum aestivum L.) after spraying of different salt solution at $50 \%$ flowering stage. This experiment was conducted at the Agricultural Experimental Station of Calcutta University, Baruipur, South 24 Parganas, West Bengal ( $88^{\circ} 26^{\prime}$ E Longitude and $22^{\circ} 22^{\prime}$ North Latitude) during the Rabi season (December to April) of 2015-16. Randomized Block Design technique was used to carry out the experiment with three replications.
Wheat variety HD 2967 was selected as the experimental unit which is a double dwarf variety with an average plant height of $92.66 \mathrm{~cm}$ [21]. It has profuse tillering. Ears are medium dense and tapering in shape with white glumes. Its grains are amber, medium bold, hard and lustrous. It is moderately resistant to yellow rust, brown rust and less susceptible to Karnal bunt and loose smut diseases [22]. It takes about 157 days to mature with an average yield of $34.95 \mathrm{q} \mathrm{ha}^{-1}$ [23].

Dilute solutions of various salts were applied at the rate of $750 \mathrm{~L} \mathrm{ha}^{-1}$ as foliar spray at $50 \%$ flowering stage. The details of the solutions were presented in Table-1. Tube well water was used for preparation of salt solution because this is easily available to farmers. The solutions were sprayed in the morning of dry sunny days.

A fertilizer does of $100 \mathrm{~kg} \mathrm{~N}, 50 \mathrm{~kg} \mathrm{P}_{2} \mathrm{O}_{5}$ and $50 \mathrm{~kg}$ $\mathrm{K}_{2} \mathrm{O}$ per ha in the form of urea, single super phosphate and muriate of potash respectively applied in the total lay out. Half of the nitrogen, entire quantity of $\mathrm{P}_{2} \mathrm{O}_{5}$ and $\mathrm{K}_{2} \mathrm{O}$ were applied at the time of final land preparation before sowing and the rest of nitrogen at the early tillering stage as top dressing.

At the time of harvest the following yield attributing characters were recorded from 10 number tillers:

$>$ Number of filled grains per panicle

$>$ Percentage of filled grains (Calculated)

$>$ Test weight $(\mathrm{g})$

$>$ Seed yield $\left(\mathrm{kg} \mathrm{ha}^{-1}\right)$

Grain and straw were separated from each sample and weight after sun drying. The yield data of each plot were converted to $\mathrm{kg} \mathrm{ha}^{-1}$ and statistical analysis was followed as advocated by some scientists [24].

\begin{tabular}{|c|c|c|}
\hline Treatments & $\begin{array}{c}\text { \% of foliar } \\
\text { spray }\end{array}$ & $\underset{1}{\text { Amount of foliar spray } L^{-}}$ \\
\hline $\mathrm{T}_{0}$ Control & & \\
\hline $\begin{array}{ll}\mathrm{T}_{1} & \mathrm{KCl}\end{array}$ & @ 0.75 & $7.5 \mathrm{~g}$ \\
\hline $\mathrm{T}_{2} \quad \mathrm{KNO}_{3}$ & @ 0.75 & $7.5 \mathrm{~g}$ \\
\hline $\mathrm{T}_{3} \quad \mathrm{KNO}_{3}$ & @ 1.0 & $10 \mathrm{~g}$ \\
\hline $\mathrm{T}_{4} \quad \mathrm{~N}: \mathrm{P}: \mathrm{K}$ & @ 1.0 & $10 \mathrm{~g}$ \\
\hline $\begin{array}{ll}\mathrm{T}_{5} & \mathrm{~N}: \mathrm{P}: \mathrm{K}\end{array}$ & @ 1.5 & $15 \mathrm{~g}$ \\
\hline $\mathrm{T}_{6} \mathrm{NaCl}$ & $@ 0.5$ & $5 g$ \\
\hline $\begin{array}{ll}\mathrm{T}_{7} & \mathrm{NaCl}\end{array}$ & @ 0.75 & $7.5 \mathrm{~g}$ \\
\hline $\mathrm{T}_{8} \quad \mathrm{~K}_{2} \mathrm{SO}_{4}$ & $@ 0.5$ & $5 \mathrm{~g}$ \\
\hline $\begin{array}{ll}\mathrm{T}_{9} & \mathrm{~K}_{2} \mathrm{SO}_{4}\end{array}$ & @ 0.75 & $7.5 \mathrm{~g}$ \\
\hline
\end{tabular}

Table 1:- Different treatment was content for foliar sprays of the experimental field 


\section{RESULTS AND DISCUSSION}

\section{Drain Filling}

The grain filling percentage in wheat (Triticum aestivum, L.) cultivar (HD 2967) under foliar application viz., water; $\mathrm{KCl} @ 0.75 \% ; \mathrm{KNO}_{3} @ 0.75 \% ; \mathrm{KNO}_{3} @ 1.0 \%$; $\mathrm{N}: \mathrm{P}: \mathrm{K} @ 1.0 \% ; \mathrm{N}: \mathrm{P}: \mathrm{K} @ 1.5 \% ; \mathrm{NaCl} @ 0.5 \%$; NaCl @ $0.75 \% ; \mathrm{K}_{2} \mathrm{SO}_{4} @ 0.5 \% ; \mathrm{K}_{2} \mathrm{SO}_{4} @ 0.75 \%$; were studied at harvest time and are being presented in Table-2.

The maximum number of filled grains (40.68) was observed with $\mathrm{NaCl} @ 0.5 \%$ treatment followed by spraying of $\mathrm{NaCl} @ 0.75 \%$. Those increments were 36.63\% and $29.02 \%$ over control respectively. The statistical analysis of grain filling was conducted and these two treatment effects are found to be at par.

All the foliar nutrient treatments recorded significantly higher number of filled grains panicle ${ }^{-1}$ over water spray under control treatment. Total number of grains panicle $^{-1}$ in $\mathrm{NaCl} @ 0.5 \%$ treated plots were found to be highest (40.68) in comparison to other foliar nutrient treatments which were $36.63 \%$ more than the control; however, the differences were statistically significant.

\section{Test Weight}

The data regarding 1000 grain weight is being presented in Table-2. All the foliar nutrient treatments recorded significantly higher test weight over water spray control treatment. Test weight was highest $\mathrm{NaCl} @ 0.5 \%$ treated plot $(43.80 \mathrm{~g})$ which is $8.59 \%$ more than the water spray control. The differences in test weight under various treatments were found to be significant.

\section{Seed Yield}

The data of grain yield presented in Table-2. The perusal of data clearly revealed that all the foliar nutrient treatments in spite of unfavorable weather condition throughout the sowing and grain filling stage, foliar application of fertilizer nutrients had significant effect on seed yield of wheat crop. The highest seed yield $(2840 \mathrm{~kg}$ $\mathrm{ha}^{-1}$ ) was observed with foliar spray application of $\mathrm{NaCl} @$ $0.5 \%$ followed by $0.75 \%$. Lowest seed yield $\left(2220 \mathrm{~kg} \mathrm{ha}^{-1}\right)$ was recorded only from water sprayed under control treatment. All the foliar nutrition treatments enhanced seed yield significantly over control treatment. The seed yield was increased up to $30.76 \%$ with the application of $\mathrm{NaCl} @$ $0.5 \%$ over control that was closely followed by $\mathrm{T}_{7}$ treatment that is spraying of $\mathrm{NaCl} @ 0.75 \%$ and this improvement was $30.76 \%$. Spraying of only KCL @ 0.75 $\%$ concentration increased seed yield significantly over control by $11.56 \%$. The increased seed yield might be due to enhanced partitioning efficiency and correcting transient nutrient deficiency during flowering and post flowering i.e. grain filling stage.

The beneficial effect of foliar nutrients during 50\% flowering and seed development might have alone created thorough production of micro-climate, congenial for grain growth of wheat. The beneficial effects of $\mathrm{N}, \mathrm{P}$ and $\mathrm{K}$ are quite high which could be attributed to their respective roles of grain filling of wheat.

\begin{tabular}{|c|c|c|c|c|}
\hline & Treatments & $\begin{array}{c}\text { Filled } \\
\text { grains panicle }\end{array}$ & $\begin{array}{c}\text { Test } \\
\text { Weight } \\
(\mathbf{g})\end{array}$ & $\begin{array}{c}\text { Seed Yield } \\
\left.\text { (kg ha }^{-1}\right)\end{array}$ \\
\hline $\mathrm{T}_{0}$ & Control & 29.78 & 40.33 & 2220 \\
\hline $\mathrm{T}_{1}$ & $\mathrm{KCl} @ 0.75 \%$ & 37.75 & 42.77 & 2660 \\
\hline $\mathrm{T}_{2}$ & $\mathrm{KNO}{ }_{3} @ 0.75 \%$ & 38.01 & 41.57 & 2480 \\
\hline $\mathrm{T}_{3}$ & $\mathrm{KNO}{ }_{3} @ 1.0 \%$ & 36.95 & 42.27 & 2420 \\
\hline $\mathrm{T}_{4}$ & $\mathrm{~N}: \mathrm{P}: \mathrm{K} @ 1 \%$ & 37.98 & 42.51 & 2380 \\
\hline $\mathrm{T}_{5}$ & $\mathrm{~N}: \mathrm{P}: \mathrm{K} @ 1.5 \%$ & 38.02 & 42.87 & 2370 \\
\hline $\mathrm{T}_{6}$ & $\mathrm{NaCl} @ 0.5 \%$ & 40.68 & 43.80 & 2840 \\
\hline $\mathrm{T}_{7}$ & $\mathrm{NaCl} @ 0.75 \% \mathrm{Na}_{0}$ & 38.42 & 43.62 & 2790 \\
\hline $\mathrm{T}_{8}$ & $\mathrm{~K}_{2} \mathrm{SO}_{4} @ 0.5 \%$ & 37.93 & 42.33 & 2370 \\
\hline $\mathrm{T}_{9}$ & $\mathrm{~K}_{2} \mathrm{SO}_{4} @ 0.75 \%$ & 36.46 & 42.62 & 2320 \\
\hline
\end{tabular}

Table 2:- Effect of treatments on number of filled grains (seeds), test weight and seed yield of wheat

Foliar application of nutrients viz. $\mathrm{KCl} @ 0.75 \%$; $\mathrm{KNO}_{3} @ 0.75 \% ; \mathrm{KNO}_{3} @ 1 \% ; \mathrm{N}: \mathrm{P}: \mathrm{K} @ 1 \% ; \mathrm{N}: \mathrm{P}: \mathrm{K} @$ $1.5 \% ; \mathrm{NaCl} @ 0.5 \% ; \mathrm{NaCl} @ 0.75 \% ; \mathrm{K}_{2} \mathrm{SO}_{4} @ 0.5 \%$; $\mathrm{K}_{2} \mathrm{SO}_{4} @ 0.75 \%$ significantly effect seed development over water sprayed control. There were increased numbers of well-developed seeds compared with sunken seeds when foliar nutrient treatments were applied as compared with the water spray controled treatment. This might be due to altered reproductive growth of the crop by supplying more nutrients to the reproductive organs resulting in less sterility more grain filling, seed development and ultimately higher yield. The improvement in yield attributes possibly is due to application of nutrients at critical stages of crop growth and those were effectively absorbed by wheat plant and translocated more effectively for proper filling and developing of seeds.

The variation in grain filling ultimately makes differences in yield, which is dependent mainly on various factors effecting the relations between source and sink. The grain filling could be favored by the enhancement in the ability of the source i.e. the flag leaf, its sheath and the spike. Wheat plants after getting chlorine nutrients inadvertently when foliar nutrients like $\mathrm{NaCl}, \mathrm{KCl}$, were applied.It was noticed that the applications of those nutrients favored in increasing the flowering and grain filling of wheat.

Therefore, it can be suggested that application the foliar sprays of chloride nutrients at the time of flowering will favor to increase the grain filling, seed weight and ultimately yield of wheat. 


\section{REFERENCES}

[1]. https://www.indiastat.com/table/agriculturedata/2/wheat-production/55991/7400/data.aspx

[2]. http://wap.business-standard.com/article/economypolicy/record-wheat-foodgrain-output-likely-in-201617-117021501141_1.html

[3]. K.I. Mosluh, J. Seth, and A.K.K. Rashid, "Efficacy of urea spray for wheat crop under irrigated conditions on Iraq," Plant and Soil, vol. 49, pp. 175-178, 1978.

[4]. M. Arif, M. A. Chohan, S. Ali, R.Gul, and S. Khan, "Response of wheat of foliar application of nutrients," J. Agric. and Bio. Sci., vol. 1(4), 30-34, 2006.

[5]. M. A. Ahmed, and M. K. A. Ahmed, "Growth and productivity of wheat plants as affected by complete foliar fertilizer compound under water stress conditions in newlycultivatedsandyland," Arab Univ. J. Agric. Sci., Ain Shams Univ., Cairo, vol. 13, pp. 269-284, 2005.

[6]. M. S. Hassanein, "Effect of variety and nitrogen levels on growth, yield and yield components of wheat (Triticum aestivum L.) in newly cultivated land,” Egypt. J. Agron., vol. 23, pp. 111-13, 2001.

[7]. Y. Emen and G. P. Moqied, "The effect of foliar spray of urea at grain filling period on grain yield and grain protein content of winter wheat,'Crops Res. Hisar, vol. 15(2-3), pp.135-139, 1998.

[8]. H. Mohammad, and M. F. Chaudhary, "Effect of foliar and soil application of NPK different growth parameters and nodulation in Lentil," Sarhad J. Agric., vol. 20(1), pp.103-111, 2004.

[9]. M. F. El-Kramany and E. Mirvat. Gobarah, "Response of fababean (ViciafabaL.) to N-Slow release fertilizer and Urea late foliar application in sandy soil," Egypt J. Agric. Res, vol. 2(1), pp. 197-207, 2005.

[10]. H.Nazim, M. A. Khan. and . M. A. Javed, "Effect of Foliar Application of Plant Micronutrient Mixtureon Growth and Yield of Wheat (TriticumaestivumL.)," Pakistan Journal of Biological Sciences, vol.8, pp.1096-1099, 2005.

[11]. K.Parvez, Y. M. Muhammad, I. Muhammad, and A. Muhammad, "Response of wheat foliar and soil application of Urea at different growth stages," Pak. J. Bot., vol. 41(3), pp.1197-1204, 2009.

[12]. A. E. Yassen, A. A. Abou El-Nour and S. Shedeed, "Response of Wheat to Foliar Spray with Urea and Micronutrients," Journal of American Science, vol. 6(9), pp. 14-22, 2010.

[13]. Ahmed, Amal, G.M.M. Tawfik and M.S. Hassanein, "Foliar Feeding of Potassium and Urea for Maximizing Wheat Productivity in Sandy Soil," Australian Journal of Basic and Applied Sciences, vol. 5(5), pp.1197-1203, 2011.

[14]. Mohamed F., H. Manal Magda Mohamed, H. A. Hamouda, M. S. Zeidan, "Effect of Urea foliar application and Potassium dihydrogen ortho phosphate on fababean yield and quality in sandy soil," International Journal of Academic Ressearch, vol. 3(6), II Part, 2011.

[15]. A.Wazir, M. Yaseen, M. Arshad, Q. Ali., "Response of Wheat (Triticumaestivum) to Foliar Feeding of
Micronutrients," International Journal for Agro Veterinary and Medical Sciences, vol. 5(2), pp. 209220, 2011.

[16]. H. Marschner, "Mineral Nutrition of Higher Plants," Annals of Botany, vol. 78(4), pp. 527-528, 1996. https://doi.org/10.1006/anbo.1996.0155

[17]. P. M. Harmer and E. J. Benne, "Sodium as a crop nutrient," Soil. Sci. Soc. Am. J., vol. 60, pp. 137-148, 1945.

[18]. A. H. Montasir, H. H. Sharoubeem, and G. H.Sidrak, "Partial substitution of sodium for potassium in water cultures," Plant Soil, vol. 25, pp. 181-194, 1966.

[19]. S. Das and A. K. Sarkar, "Effect of post flowering spray of KNO3 solution of grain filling and yield of rice and wheat," Indian Agric., vol. 25, pp. 267 - 273, 1981.

[20]. B. A. Hedge, and S. M. Karande, "Efficacy of presowing treatment of sodium chloride on the incidence of green ear disease of Pennisetum typhoides (Burm.) Stapf and Hubb. var. HB3," Plant and soil, vol. 49, pp. 551-559, 1978.

[21]. N. Ali, A. Dayal, G.M. Lal, N. Thomas, and T. Singh, "Effect Of Early and Mid Sowing on Growth and Yield of Wheat (Triticum aestivum L.) Varieties," Int. J. Pure App. Biosci., vol.6(3), pp. 403-409, 2018. doi: http://dx.doi.org/10.18782/2320-7051.6719

[22]. P. Rani, G. S. Rattan, and A. Singh, "Assessment of Karnal Bunt Disease of Wheat in Different Districts of South Western Punjab," International Journal of Scientific and Research Publications, vol.7(8), pp. 126-131, 2017.

[23]. D. Mukherjee, "Yield Maximization of Wheat (Triticum aestivum L.) Cultivars through Improved Water Management Strategy," International Journal of Bioresource Science, vol. 3(2), pp. 67-71, 2016. DOI: 10.5958/2454-9541.2016.00017.7.

[24]. V.G. Panse, and P.V. Sukkatme, "Statistical Methods for Agricultural Workers," Indian Council of Agricultural Research, New Delhi, 1954. 